\title{
Distribution of Food Reserves in Snowberry
}

\section{(Symphoricarpus oreophilus)}

\section{MELVIN R. GEORGE AND C. M. MCKELL}

Highlight: A study was conducted in northern Utah in 1974 to determine the distribution of nonstructural carbohydrates (NC) and lipids in snowberry (Symphoricarpus oreophilus). Snowberry biomass was sampled and partitioned into small roots, large roots, root crowns, old stems, new stems, and leaves, which were analyzed for NC and lipids. The results showed a generally larger pool of NC in stems than in belowground biomass. Lipids in snowberry remained relatively stable throughout the growing season and included relatively small amounts of those lipids most likely to enter metabolism. Thus, lipids apparently do not contribute significantly to the carbon reserve pool.

Plant food reserves are largely nonstructural carbohydrates (NC) but lipids may also be a source of reserve carbon (Cook 1966). Lipids have received little attention as potential food reserves in range plants but have been investigated in alpine plants (Bliss 1962; McCown and Tieszen 1972). Fluctuating lipid concentrations might indicate additional reserve potential because seasonal fluctuations of reserve compounds imply metabolic use and replacement. Conversely, seasonal constancy of lipid concentrations or qualities indicates that lipids are relatively unimportant as reserve compounds under normal conditions.

Seasonal trends in NC concentrations have been described for many range plants by various researchers (Cook 1966; White 1973), but few researchers have described NC distri-

Authors are assistant professor, Natural Resources Management Department, California Polytechnic State University. San Luis Obispo 93407; and director, Institute for Land Rehabilitation, Utah State University, Logan 84322 .

Manuscript received June 21, 1977. bution on a quantity basis. Priestly (1962) stated that it was desirable to determine the total quantity of carbohydrate reserves in plant storage organs rather than only the concentration of carbohydrate reserves.

Whereas concentration measures of carbohydrates have been used to illustrate the time sequence of reserve depletion and replenishment, they fail to give an accurate estimate of the amount of carbohydrate reserves in the plant. Reserve amounts can only bc determined on an absolute basis, which requires an estimate of total plant biomass.

In this study, NC and lipids were determined both on a concentration and a quantity basis to show the distribution in selected plant parts, and to determine seasonal changes in lipid and NC quantities.

\section{Methods}

Biomass of snowberry (Symphoricarpus oreophilus Gray) was collected in late April, mid-May and mid-August in 1974 near the Utah State University Forestry
Summer Camp in Logan Canyon $42 \mathrm{~km}$ northeast of Logan, Utah. Plants and clones were excavated separately because they have different growth habits. A plant has a single stem at the ground surface with a correspondingly small basal area. In contrast, a clone has a large basal area because many single stems are connected underground by the root crown.

Auger samples were taken radially from plants and clones at several depths in each radial stratification to determine the soil volume that must bc excavated to remove root biomass (Schuurman and Goedewaagen 1971). Roots did not extend beyond $31 \mathrm{~cm}$ from the stem of single plants or the outer stems of clones. Root depth was limited to $61 \mathrm{~cm}$ by the rocky soil at that depth and the claypan at $76-81 \mathrm{~cm}$. Root material belonging to understory species and adjacent shrubs was identified and removed from the soil volume. The remaining root material was sieved, washed and floated from the soil using methods similar to those of McKell et al. (1961). All plant material was dried $\left(80^{\circ} \mathrm{C}\right)$ and weighed to determine biomass.

Total biomass over the range of plant and clone sizes varied so greatly that the biomass was separated into four size classes: large clones ( 7 to $15.5 \mathrm{~kg}$ ), small clones $(2.5$ to $7 \mathrm{~kg})$, large plants $(0.95$ to $3.5 \mathrm{~kg})$, and small plants $(0.25$ to $0.95 \mathrm{~kg})$. Ten individuals in each size class were excavated. This sample size was great enough to insure a coefficient of variation of $\pm 15 \%$ at the $90 \%$ level of probability.

During the three periods of biomass sampling, random samples of leaves, new stems, old roots, root crowns, large roots, and small roots (less than $6 \mathrm{~mm}$ in 
diameter) from four plants or clones werc frozen in dry ice for analysis of NC and lipids. This sample size was adequate to insure that $95 \%$ of the observations fell within $10 \%$ of the mean.

Frozen plant samples were stored in a freezer and were later freeze-dried. The freeze-dried samples were ground in a Wiley Mill through a 40 -mesh screen. The ground plant material was stored in desiccators

The NC was extracted from the ground plant samples using $0.2 \mathrm{~N}$ sulfuric acid as described by Smith et al. (1964). This method hydrolyzed NC to reducing sugars, which were analyzed using the dinitrosalicylic acid method (Luchsinger and Corncsky 1962). Glucosc was used as a standard. The product of this procedure has conventionally been called total available carbohydrates but this term is a misnomer according to Stoddart et al. (1975) and George (1976).

Lipid extractions were conducted by the method of Fonnesbeck and Harris (1974) that was similar to the method of McCown (1973). As a gross index to the availability of the total lipids, each extract sample was saponified using alcoholic potassium hydroxide. The amount of potassium taken up by the total lipid was an index of the amounts of triglycerides and their component compounds in the total lipid fraction. The saponified lipid was then titrated with a standard acid to determine the amount of potassium hydroxide $(\mathrm{KOH})$ left after the completion of saponification. The saponification number is the number of milligrams of $\mathrm{KOH}$ consumed in the complete saponification of one gram of fat or oil (Clark 1964).

Duplicate laboratory analyses were conducted periodically to check methods and stock solutions. Duplicate analyses were also conducted if there was any reason for doubting some determinations.

Analyses of variance and $F$-tests were performed on all data. The calculated $F$ values were tested at the 1 and 5\% levels of probability. Duncan's new multiple range test (Duncan 1955) was used at the $5 \%$ level to separate means that differed significantly.

\section{Results and Discussion}

\section{Biomass}

The four size classes of snowberry biomass measured in late April, midMay, and mid-August were not intended to estimate plant production, but only as a measure of the biomass of various plant parts at three important points along the seasonal NC cycle. The belowground and old stem biomass of the three smallest size classes (small clones, large plants, and small plants) did not change significantly over the three collection periods (Fig. 1). Even
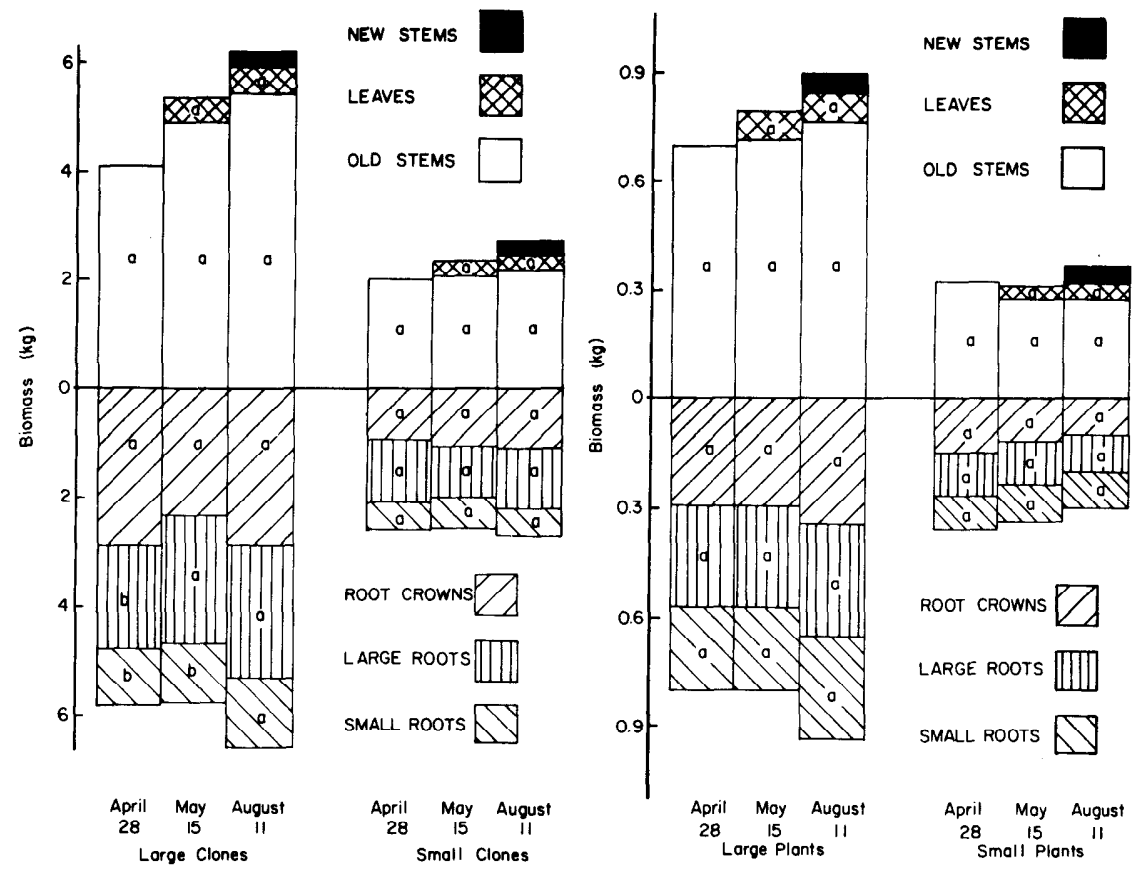

Fig. 1. Biomass of various plant parts of snowberry. Means for the same plant part with the same letter are not significantly different $(P>0.05)$. la (left) large and small clones; lb (right) large and small plants.

the increase in biomass resulting from leaf production and stem elongation did not significantly increase the total biomass.

Increases in below ground biomass in large plants and large clones over the three collection dates may be attributed to natural variation and sampling error. On the first sampling date the soil was extremely wet and sticky, probably hampering root recovery. On the second sampling date, the soil consistency had improved but was still somewhat sticky. On the third collection date the soil was quite friable and root recovery was improved.

\section{Lipids}

Lipid concentration did not change significantly over the three collection dates in any of the plant parts except leaves (Table 1). Leaf lipid concentrations were $5.8 \%$ and $7.1 \%$, respective-

ly, for the second and third collection dates. Lipid concentrations in other plant parts were much lower. The National Academy of Science (1971) reported that other extracts of lipids were between 2 and $5 \%$ for snowberry browse.

Lipid concentration values were multiplied by biomass data to provide an estimate of the quantity of lipids in each plant part (Fig. 2). Although lipid concentrations did not change significantly over the three collection dates, their quantities varied because of changes in biomass.

The saponification number (mg $\mathrm{KOH}$ consumed/g of lipid) for the lipid fraction from small roots was significantly lower on May 15 than on April 28 and did not increase significantly by August 11 (Table 1). The saponification number in large roots was

Table 1. Mean lipid concentration (\%) and saponification number (mg KOH consumed/g of lipid) for each plant part of snowberry on the three dates.

\begin{tabular}{|c|c|c|c|c|c|c|}
\hline \multirow[b]{3}{*}{ Plant part } & \multicolumn{6}{|c|}{ Dates } \\
\hline & \multicolumn{2}{|c|}{$4 / 28 / 74$} & \multicolumn{2}{|c|}{$5 / 15 / 74$} & \multicolumn{2}{|c|}{$8 / 11 / 74$} \\
\hline & $\begin{array}{c}\text { Lipid } \\
(\%)\end{array}$ & $\begin{array}{l}\text { Saponi- } \\
\text { fication } \\
\text { number }\end{array}$ & $\begin{array}{c}\text { Lipid } \\
(\%)\end{array}$ & $\begin{array}{l}\text { Saponi- } \\
\text { fication } \\
\text { number }\end{array}$ & $\begin{array}{l}\text { Lipid } \\
(\%)\end{array}$ & $\begin{array}{l}\text { Saponi- } \\
\text { fication } \\
\text { number }\end{array}$ \\
\hline Small roots & $0.90 c^{1}$ & $51.40 \mathrm{bcd}$ & $0.93 \mathrm{c}$ & $19.40 \mathrm{e}$ & $1.09 \mathrm{c}$ & 44.92 bcde \\
\hline Large roots & $0.74 \mathrm{c}$ & 50.80 bcde & $0.61 \mathrm{c}$ & $108.82 \mathrm{a}$ & $0.74 c$ & $76.34 b$ \\
\hline Root crowns & $1.03 \mathrm{c}$ & 45.04 bcde & $0.79 \mathrm{c}$ & $63.75 \mathrm{bc}$ & $0.91 \mathrm{c}$ & $55.56 \mathrm{bcd}$ \\
\hline Old stems & $1.55 \mathrm{c}$ & 49.13 bcde & $1.32 \mathrm{c}$ & $43.67 \mathrm{cde}$ & $1.33 \mathrm{c}$ & $36.09 \mathrm{cde}$ \\
\hline Leaves & - & - & $5.84 \mathrm{~b}$ & $45.66 \mathrm{bcde}$ & $7.09 \mathrm{a}$ & $36.41 \mathrm{cde}$ \\
\hline New stems & - & - & - & - & $1.71 \mathrm{c}$ & $24.83 \mathrm{de}$ \\
\hline
\end{tabular}

'All means for each chemical analysis followed by the same letter are not significantly different $(P>0.05)$. 

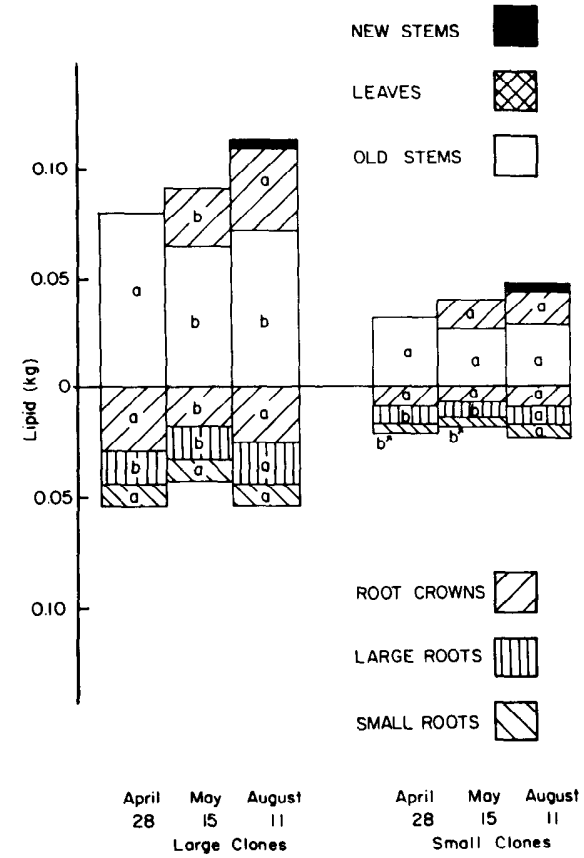

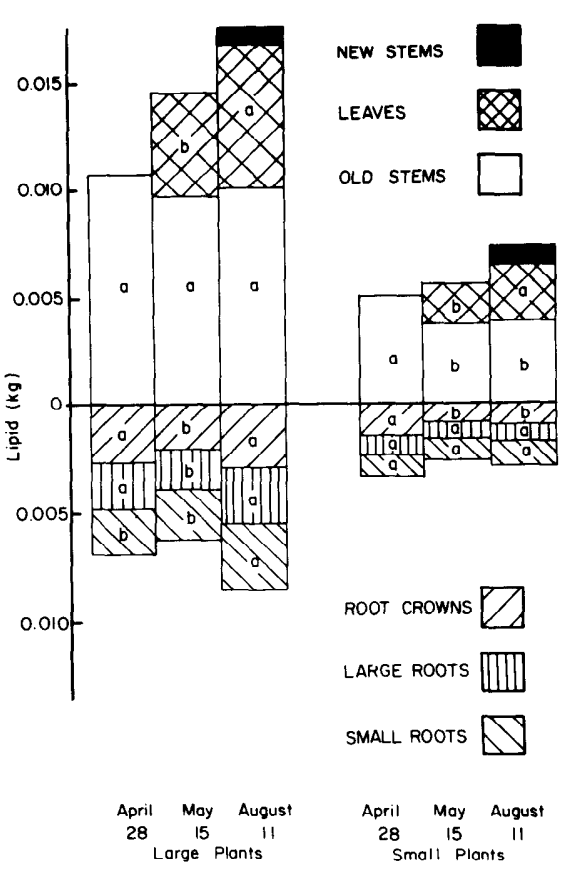

Table 2. Mean nonstructural carbohydrate concentration (\%) for each plant part of snowberry on three dates.

\begin{tabular}{lcrr}
\hline & \multicolumn{3}{c}{ Dates } \\
\cline { 2 - 4 } Plant parts & $4 / 28 / 74$ & $5 / 15 / 74$ & $8 / 11 / 74$ \\
\hline Small roots & $11.52 \mathrm{c}^{1}$ & $5.75 \mathrm{f}$ & $12.47 \mathrm{c}$ \\
Large roots & $4.89 \mathrm{f}$ & $5.03 \mathrm{f}$ & $5.07 \mathrm{f}$ \\
Root crowns & $5.72 \mathrm{f}$ & $5.72 \mathrm{f}$ & $5.52 \mathrm{f}$ \\
Old stems & $8.47 \mathrm{e}$ & $5.53 \mathrm{f}$ & $10.43 \mathrm{~d}$ \\
Leaves & - & $25.88 \mathrm{a}$ & $17.28 \mathrm{~d}$ \\
New stems & - & - & $10.01 \mathrm{~d}$ \\
\hline
\end{tabular}

'All means followed by the same letter are not significantly different $(p>0.05)$.

The concentration of NC in large roots and root crowns was relatively stable throughout the seasonal cycle.

Significant variation in NC quantity was observed in small roots and old stems of all size classes (Fig. 3). Nonstructural carbohydrate quantity in large roots and root crowns remained stable except in large clones, where significant changes in large root biomass caused a change in large root NC quantity.

Leaf quantity decreased between May and August. This was primarily because of a drop in NC concentration from 25.9 to $17.3 \%$ (Table 2). New stems had NC concentrations similar to those measured in old stems in August. New stem NC quantity represented a statistically insignificant increase in total biomass NC quantity on an annual basis. Nonstructural carbohydrates were determined at the end of dormannumber was similar to that found in old stems.

Saponifiable lipids, such as fats and phosopholipids, are more likely to enter metabolism and become an energy source than are nonsaponifiable lipids (Mooney and Chu 1974). Saponification numbers are an indicator of the proportion of the lipid fraction which might enter metabolism. For example, each mole of fat, with three fatty acid side chains per molecule, requires three moles of $\mathrm{KOH}$ for complete saponification. The low saponification numbers determined for lipids extracted from snowberry indicate that only part of the lipids are likely to enter metabolism. Clark (1964) reported saponification numbers of 183 to 207 for readily metabolizable lipids such as linseed oil, corn oil, almond oil, and olive oil. These numbers are twice as great as the highest saponification number determined for snowberry lipids. Mooney and Chu (1974) found only small amounts of carbon devoted to saponifiable compounds in Heteromeles arbutifolia. The lack of seasonal fluctuation and only partial availability

of lipids indicate that they are probably not important food reserves under normal conditions.

\section{Nonstructural Carbohydrates}

Nonstructural carbohydrate concentrations in small roots and old stems varied significantly throughout the seasonal cycle of snowberry (Table 2). Donart (1969) reported similar findings for NC concentration in small roots.

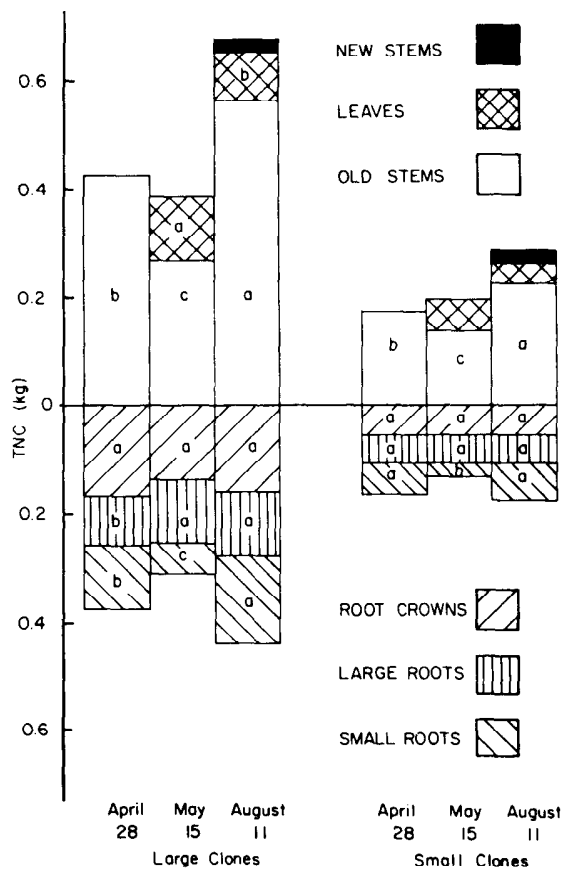

Fig. 3. Nonstructural carbohydrate quantity in various plant parts of snowberry. Means for the same plant with the same letter are not significantly different $(P>0.05) .3 a$. large and small clones; $3 b$. large and small plants. 
cy, at the approximate $\mathrm{NC}$ low and again at the annual NC maximum following replenishment with photosynthates. Snowberry reached a maximum level of $\mathrm{NC}$ in each of its plant parts before entering dormancy. During dormancy the NC pool was partially depleted. Near the end of dormancy buds below the snow and litter level broke dormancy and began elongating even though the soil surface was still covered with snow. Thus, depletion of NC during dormancy was not used exclusively for respiration. When the buds in the stems began to swell, indicating the end of dormancy, the NC quantity measured in perennial plant parts was 21 to $25 \%$ lower than the NC quantity measured at the summer maximum in large plants and large and small clones. The NC quantity in perennial plant parts of small plants was only $7.5 \%$ lower at the end of dormancy than at the summer maximum.

From the onset of bud swelling in late April, $\mathrm{NC}$ was further depleted as the plant began spring leaf production. Carbon reserve depletion was at its lowest point by mid-May or early-June. The NC quantities in perennial plant parts were 41 to $46 \%$ lower than the summer maximum in all four size classes. From June until mid-August, $\mathrm{NC}$ was replenished in all plant parts. Stem growth occurred during this period as well as limited flower pro duction and seed set.

From a seasonal aspect, the distribution of NC changes between aboveground biomass and belowground biomass. Old and new stem NC quantity was greater than the belowground NC quantity in mid-August in all four size classes, but only in large clones and large plants on the first collection date. In contrast, belowground NC quantity was greater than old and new stem NC quantity in mid-May.

McConnell and Garrison (1966) found that bitterbrush roots maintained the greater quantity of reserve carbohydrates except in June and July when the NC depletion point was reached. Sprague and Sullivan (1950) found that although roots had lower concentrations of carbohydrate reserves than other storage organs in some grasses, the total quantity of carbohydrates stored in roots was greater because of the greater mass of roots. In snowberry the mass of old stems is less than the mass of total roots, but the higher NC concentration of old stems shifts the
NC quantity balance to the stems, except at the annual NC low points.

Nonstructural carbohydrate concentration fluctuation is commonly considered an indicator of the relative contribution of NC by each plant part, but this ignores the importance of plant parts where NC concentration shows little seasonal change. Little seasonal NC concentration fluctuation could indicate rapid replacement of $\mathrm{NC}$ from another source, or a small contribution of NC to plant metabolism. George (1976) showed that NC concentration in large roots and root crowns decreased in response to defoliation. In the present study, small roots and old stems showed seasonal variations in $\mathrm{NC}$ concentration but large roots and root crowns did not. Large roots and root crowns together usually contained a greater NC quantity than small roots. A large NC pool could make an important contribution to metabolism without showing a significant decrease in $\mathrm{NC}$ concentration. In many studies $\mathrm{NC}$ concentration in small roots is most responsive to changes in NC sources and sinks. The inference is that the plant is in a vulnerable state when NC concentrations drop from the annual maximum to the spring depletion point. This interpretation ignores any $\mathrm{NC}$ in larger roots and root crowns, which may moderate the effect of NC concentration decreases in small roots.

\section{Conclusions}

Lipids did not fluctuate on a seasonal basis and only a small proportion of the lipid compounds was available for plant metabolism in snowberry. Therefore, lipids arc believed not to be important as food reserves in snowberry under normal conditions. The NC quantity balance shifts from the aboveground biomass to the belowground biomass when reserves are at their lowest level in mid-May. This may indicate that aboveground biomass contributes more carbohydrate reserves during spring leaf production than belowground biomass. Finally, the tendency to imply plant carbohydrate status from onc sensitive plant part, such as small roots, should be avoided because it ignores the contribution of other plant parts to the whole plant NC pool.

\section{Literature Cited}

Bjerregaard, R.S. 1971. The nitrogen budget of two salt desert shrub plant communities of western Utah. PhD Diss., Utah State University, Logan. $100 \mathrm{p}$.
Bliss, L. S. 1962. Caloric and lipid content in alpine tundra plants. Ecology 43:753-757.

Clark, J. M. 1964. Experimental Biochemistry. p. 47-54. W. H. Freeman and Co., San Francisco, Calif.

Cook, C. W. 1966. Carbohydrate reserves in plants. Utah Agr. Exp. Sta., Resources Ser. $31.47 \mathrm{p}$.

Donart, G. B. 1969. Carbohydrate reserves of six mountain range plants as related to growth. J. Range Manage. 22:411-415.

Duncan, D. B. 1955. Multiple range and multiple F test. Biometrics 11:1-42.

Fernandez, O. A. 1974. The dynamics of root growth and the partitioning of photosynthates in cool desert shrubs. PhD Diss., Utah State University, Logan. 120 p.

Fonnesbeck, P. B., and L. E. Harris. 1974. Determining solvent extract and nutritive lipid. Proc., Western Section, Amer. Soc. Anim. Sci. 25:1-4.

George, M. R. 1976. Distribution of carbon reserves in snowberry (Symphoricarpus oreophilus). PhD Diss., Utah State Univ., Logan. $73 \mathrm{p}$.

Luchsinger, W. W., and R. A. Cornesky. 1962. Reducing power by the dinitrosalicylic acid method. Anal. Biochem. 4:346-347.

McConnell, B. R., and G. A. Garrison. 1966. Seasonal variations of available carbohydrates in bitterbrush. J. Wildl. Manage. 30;168-172.

McCown, B. H. 1973. Growth and survival of northern plants at low soil temperatures, growth response, organic nutrients, and ammonium utilization. Special Rep. 186. Cold Regions Res. and Eng. Lab., Hanover, New Hampshire.

McCown, B. H., and L. L. Tieszen. 1972. A comparative investigation of periodic trends in carbohydrate and lipid levels in arctic and alpine plants. Proc., 1972 U.S. Tundra Biome Symp.

McKell, C. M., A. M. Wilson, and M. B. Jones. 1961. A floatation method for easy separation of roots from soil samples. Agron. J. 53:56-57.

Mooney, H. A., and C. Chu. 1974. Seasonal carbon allocation in Heteromeles arbutifolia, a California evergreen shrub. Oecologia 14: 195-306.

National Academy of Science. 1972. Atlas of nutritional data on United States and Canadian feeds. Printing and Publishing Office, Nat. Acad. Sci., Washington, D.C. 772 p.

Priestly, C. A. 1962. Carbohydrate resources within the perennial plant; their utilization and conservation. Commonwealth Bur. Hort. and Plantation Crops. Tech. Communication 27. $116 \mathrm{p}$.

Schuurman, J. J., and M. A. J. Goedewaagen. 1971. Methods for examination of root systems and roots (2nd ed.). Center for Agricultural Publications and Documentation, Wageningen, The Netherlands. $86 \mathrm{p}$.

Smith, D., G. M. Paulsen, and C. A. Raguse. 1964. Extraction of total available carbohydrates from grass and legume tissue. Plant Physiol. 39:960-962.

Sprague, V. G., and J. T. Sullivan. 1950. Reserve carbohydrates in orchard grass clipped periodically. Plant Physiol. 25:92-102.

Stoddart, L. A., A. D. Smith, and T. W. Box. 1975. Range Management. 3rd ed. McGrawHill Book Co., Inc., New York. 532 p.

White, L. M. 1973. Carbohydrate reserves of grasses: A review. J. Range Manage. 26: 13-18. 